\title{
Analytical Hierarchy Process as a Tool for Investment Appraisal
}

\author{
Ceren Oral ${ }^{1}$ \\ ${ }^{1}$ Department of Economics and Finance, Fethiye Faculty of Management, Mugla Sitk1 Kocman University, \\ Fethiye, Turkey \\ Correspondence: Ceren Oral, Assistant Professor, Department of Economics and Finance, Fethiye Faculty of \\ Management, Mugla Sitk1 Kocman University, Fethiye, Turkey. E-mail:ceren.uzar@gmail.com
}

Received: March 9, 2016

Accepted: March 24, 2016

Online Published: March 25, 2016

doi:10.5539/ijef.v8n4p306

URL: http://dx.doi.org/10.5539/ijef.v8n4p306

\begin{abstract}
Analytic Hierarchy Process (AHP), is the method of multiple-criteria decision analysis. AHP; severity of the important criteria in deciding the pairwise comparisons and it carries out the sequence of decisions alternatives. AHP is a powerful and easy to understand method that allows combining qualitative and quantitative factors in the decision making process for groups and individuals.

AHP in finance is a frequently used method especially financial performance appraisal, credit appraisal, the financial failure prediction, estimation of the exchange rate and the selection of projects. Evaluation and selection of projects is a difficult task before making investment decisions. In this context, it has been developed a case study to determine the best project by applying the AHP technique. For this purpose, considering four criteria, the best projects between options have been identified and evaluated by alternative four projects.
\end{abstract}

Keywords: Analytical Hierarchy Process (AHP), investment appraisal, decision making

\section{Introduction}

Decision making is the basis of all management functions. Therefore, it is necessary to take the right decisions to gain and maintain competitive advantage (Kuruïzüm \& Atsan, 2001). Multi-criteria decision-making methods, when people deal with complex decisions covering various sizes are designed to help them make better choices (Lin et al., 2013). AHP is a quite widely used multi-criteria decision-making method. AHP; applied in many areas, helps in selecting the best alternative for decision makers in case of Multi-Criteria Decision Making.

AHP in decision-making, it is a mathematical method of assessing qualitative and quantitative variables together, considering the priorities of the group or individual (Tekindal \& Erümit, 2007). The purpose of the AHP, by being placed to a scale of priorities for the given set of choices, the intuitive judgment and decision-makers taking into consideration the consistency comparison of the options in the decision-making process and to ensure the completion of this process in the most efficient manner (Özyörük \& Özcan, 2008). The most important feature of the AHP, the decision-making process as a visual multi-criteria decision problem can be seen in the form of hierarchy (Çelik \& Topsakal, 2015).

In this study, after the introduction part, it was carried out a literature review of the AHP's application on finance, and focused on the implementation of AHP. Then, by using the AHP method, it has developed a case study on investment appraisal. In this context; net present value, benefit cost analysis, rate of return and payback period is determined as a criterion.

\section{Literature Review}

AHP, although widely used in finance, it is a method often used especially financial performance evaluation, credit evaluation, the prediction of financial failure, exchange rate estimate and project selection. In the literature; it is possible to come across studies in the field of finance in this way.

Ülengin and Ülengin (1994) have benefited from the AHP method to estimate the exchange rate. Babic and Plazibat (1998), using the AHP method, they measure the level of efficiency in the provision of company operation. Hogan et al. (2000) have developed a model that predicts financial failure with the help of AHP.

İç and Yurdakul (2000) have developed a model using financial ratios for banks in the credit assessment. They have benefited from the AHP in the creation of this model. The creation of the model; "Subjectively credit worthiness, the state of the sector in which they operate and loan guarantees" were used as qualitative and 
quantitative factors together. Yang and Shia (2002), have used the AHP method to evaluate the performance of the company.

Atan et al. (2004) studied of the demand for credit in a bank with AHP method and evaluated the process of deciding acceptance or rejection of the loan amount. Yurdakul and İç (2004); they perform their work in manufacturing enterprises with the use of credit ratings by AHP method. Sekreter et al. (2004) have developed sample a model in the study by using financial ratios with AHP method, for the grading of the creditworthiness of companies in the food sector traded on the ISE.

Albayrak and Erkut (2005) by establishing criteria for performance evaluation system that uses a multi-purpose one in non-financial and financial services system have developed a model for assessing the performance of a service system of the bank business.

Bodur and Teker (2005) in their study have developed credit scoring models in decision-sufficiency. Yüksel and Akın (2006) have used the AHP method to strategize in business. Bayraktar and Ege (2008) have developed a model for assessing financial performance using financial ratios of the bank in their studies.

Palcic and Lalic (2009) have identified the best project by using AHP method after evaluating them all, on their studies. Akkaya and Demireli (2010) by financial ratios of the company which is the key performance indicators of credit institutions using the AHP method in the study developed a model which relates weight to the need for evaluation.

Koç (2013) which they are more effective in managing the risks faced by banks in Turkey, their appropriate methods which they apply, scoring the AHP and the severity of the risk has been analyzed by the method on the study.

\section{Stages of the AHP}

In this section, stages of the AHP will be explained.

\subsection{Establishing the Model (Hierarchical Structure) and Formulating the Problem}

In the AHP method; the preference for solving problems in a hierarchical structure means the separation of the various levels of problems. The hierarchical structure of the creation process is called modeling (Peng \& Dai, 2009; Chandran et al., 2005). After hierarchy is created, the relative importance of the criteria level against each other is calculated. Decider; based on scale of 1-9, decide the degree of importance of the criteria. In Table 1, 1-9 scale that is utilized, are described in detail (Saaty, 2008).

Table 1. 1-9 scale used in binary comparison method

\begin{tabular}{cc}
\hline Degrees & Definition \\
\hline 1 & Equal Importance \\
3 & Moderate importance \\
5 & Strong Importance \\
7 & Very strong or demonstrated importance \\
9 & Extreme importance \\
$2-4-6-8$ & Consensus (average) values \\
\hline
\end{tabular}

\subsection{Establishment of Bilateral Comparison Matrix and Determination of Weight}

As the second step aside the AHP, it comes pairwise comparisons matrix. After you create a hierarchical structure, it is calculated relative significance of each criterion (Chandran et al., 2005). Criteria matrixes for pairwise comparisons are shown in Table 2 (Saaty, 1990; Chandran et al., 2005).

Table 2. Creating comparison bilateral criteria matrix

\begin{tabular}{ccccc}
\hline & Criterion 1 & Criterion 2 & Criterion $\ldots$ & Criterion $\mathrm{j}$ \\
\hline Criterion 1 & $\mathrm{~W} 1 / \mathrm{W} 1$ & $\mathrm{~W} 1 / \mathrm{W} 2$ & $\ldots$ & $\mathrm{W} 1 / \mathrm{Wj}$ \\
Criterion 2 & $\mathrm{~W} 2 / \mathrm{W} 1$ & $\mathrm{~W} 2 / \mathrm{W} 2$ & $\ldots$ & $\mathrm{W} 2 / \mathrm{Wj}$ \\
Criterion... & $\ldots$ & $\ldots$ & $\ldots$ & $\ldots$ \\
Criterion I & Wi/W1 & Wi/W2 & $\ldots$ & $\mathrm{Wi} / \mathrm{Wj}$ \\
\hline
\end{tabular}




\subsection{The Establishment of Normalized Matrix}

The normalized matrix is obtained by dividing the total individual corresponding column to each column value. From-normalized matrix motion; the average value of each row is taken. The obtained values are percentages by weight for each criterion value (Palaz \& Kovanc1, 2008). The other pace is to classify numerical values to the dimensions, such as poor, fair, good, very good and excellent. We can make a change on these values if necessary because it can't be appropriate for all situations. To these qualitative dimensions, we give a numerical value between 0 and 1 . It is up to us what value is given to each dimension. As an example: poor-value 0,0 ; fair-value 0,1 ; good- value 0,3 ; very good-value 0,6 ; excellent-value 1,0 (Palcic \& Lalic, 2009). We can find the total grade of the project with the following formula;

$$
P=W 1 * K 1+W 2 * K 2+\ldots .+W n * K n
$$

$\mathrm{P}$ : total grade of the project, $\mathrm{W}$ : weight of criteria and $\mathrm{K}$ : the numerical value of the dimension.

\subsection{Calculating Consistency Rate}

The final stage is to have the consistency rate. Saaty suggests using the following formula to calculate the consistency of the comparison matrix. (Zhou \& Shi, 2009; Saaty \& Özdemir, 2003).

$$
C R(\text { Consistency Ratio })=C I(\text { Consistency Index }) / R I(\text { Random Index })
$$

For the calculation of Consistency indicator (CI) ,the following formula is required (Zhou \& Shi, 2009):

$$
C I=\lambda \max -n / n-1
$$

$\mathrm{CR}$ is obtained by comparing a set of the given number below by CI. If the CR is smaller than 0.10 , the decision-makers pairwise comparisons are relatively consistent. If the $\mathrm{CR}$ is bigger than 0.10 , the decision-maker should seriously consider re-evaluating his/her pair-wise comparisons. Random index numbers are given in Table 3.

Table 3. Random index numbers

\begin{tabular}{ccccccccccc}
\hline $\mathrm{N}$ & 1 & 2 & 3 & 4 & 5 & 6 & 7 & 8 & 9 & 10 \\
\hline $\mathrm{RI}$ & 0 & 0 & 0.58 & 0.90 & 1.12 & 1.24 & 1.32 & 1.41 & 1.45 & 1.49 \\
\hline
\end{tabular}

\section{Case Study}

Assume that the management wants to choose the best project amongst all proposed projects. In this study, four criteria are chosen for evaluating the projects. These are net present value (NPV), benefit-cost analysis (BC), rate of return (ROR) and payback period (PP) and there are four projects with different values depending on the criteria. First, hierarchy structure should be made. As it is seen in Table 4, Evaluation matrix shows the hierarchy structure.

Table 4. Evaluation matrix

\begin{tabular}{ccccc}
\hline & ROR & PP & NPV & BC \\
\hline ROR & 1 & 2 & 1 & 1 \\
PP & 0,5 & 1 & 0,5 & 0,75 \\
NPV & 1 & 2 & 1 & 2 \\
BC & 1 & 1,33 & 0,5 & 1 \\
Total & 3,5 & 6,33 & 3 & 4,75 \\
\hline
\end{tabular}

Then, normalized decision matrix is constructed. The results are as shown in Table 5.

Table 5. Normalized matrix

\begin{tabular}{lllllll}
\hline & ROR & PP & NPV & BC & Total & Weights \\
\hline ROR & 0,285714 & 0,315956 & 0,333333 & 0,210526 & 1,14553 & 0,286382 \\
PP & 0,142857 & 0,157978 & 0,166667 & 0,157895 & 0,625396 & 0,156349 \\
NPV & 0,285714 & 0,315956 & 0,333333 & 0,421053 & 1,356056 & 0,339014 \\
BC & 0,285714 & 0,210111 & 0,166667 & 0,210526 & 0,873018 & 0,218254 \\
\hline
\end{tabular}


The next step is to select qualitative dimensions and to assign numerical values to them on scoring scale. In this study, qualitative dimensions and numerical values of them are determined as follows: Poor value 0,0 ; fair value; 0,15 ; good value 0,35 ; very good value 0,7 ; excellent value 1,0 .

Each project must be analyzed individually and must be decided what level of fulfillment each selected criteria is.

Table 6 shows each project scores and also ranking.

Table 6. Calculation of the score of each projects

\begin{tabular}{lcccccc}
\hline & ROR & PP & NPV & BC & Score of Projects & Ranking \\
\hline Project 1 & 1,0 & 1,0 & 0,7 & 1,0 & 0,898296 & 0,593492 \\
Project 2 & 0,35 & 1,0 & 0,35 & 1,0 & 0,756508 & 4 \\
Project 3 & 1,0 & 0,35 & 1,0 & 0,35 & 0,867181 & 3 \\
Project 4 & 0,7 & 0,7 & 1,0 & 1,0 & 2 \\
\hline
\end{tabular}

Finally Project 1 got the highest score. Obviously, it is the best alternative for the organization. The next step is to calculate the CR. Table 7 shows the Lambda-max value and Table 8 shows the value of CR.

Table 7. Calculation of the lambda-max

\begin{tabular}{cc}
\hline ROR & 1,002338 \\
PP & 0,98969 \\
NPV & 1,017042 \\
BC & 1,036709 \\
Lambda-max & 4,045779 \\
\hline
\end{tabular}

As it is seen in Table 8 the CR is 0,016955 and the value of the CR is smaller than 0,10 so the result of this study is consistent.

Table 8. Calculation of the consistency ratio

\begin{tabular}{ccc}
\hline CI & RI & CR \\
\hline 0,01526 & 0,9 & 0,016955 \\
\hline
\end{tabular}

\section{Conclusion}

In view of the fact that evaluating projects is a problem, yet often it is a difficult task. It is complicated, because there is usually more than one dimension for measuring the impact of each project and especially when there is more than one decision maker. Multi-criteria decision-making methods; helps to make better decisions in creating viable options where there are conflicting objectives such as decision makers of uncertainty, complexity.

In this study; applying the AHP, multi-criteria decision-making methods, it has tried to determine the best project. For this purpose, four projects were evaluated considering four alternative criteria. The criteria are defined as, which have importance in the evaluation of investment projects "net present value, benefit-cost analysis, rate of return and payback period". Each project is defined according to whether the individual evaluation criteria, and is showed the importance in numerical values. Then, the availability of valuation of projects was carried out scores of each project. Finally; the best project was project 1 and it was followed by project 4, project 3 and project 2 .

\section{References}

Akkaya, G. C., \& Demireli, E. (2010). Analitik Hiyerarşi Süreci ile Kredi Derecelendirme Analizi Üzerine Bir Model Önerisi. Ç.Ü. Sosyal Bilimler Enstitüsü Dergisi, 19(1), 319-335.

Albayrak, Y. E., \& Erkut H. (2005). Banka Performans Değerlendirmede Analitik Hiyerarşi Süreç Yaklaşımı. ITÜ Dergisi/d Mühendislik, 4(6), 47-58.

Atan, M., Maden, U., \& Akyıldı,, E. (2004). Analitik Hiyerarşi Süreci (AHS) Kullanımı ile Bir Bankada Kredi Taleplerinin Değerlendirilmesi. VIII. Ulusal Finans Sempozyumu, Istanbul. 
Babic, Z., \& Plazibat, N. (1998). Ranking of Enterprises Based on Multicriterial Analysis. International Journal of Production Economics, 56-57, 29-35. http://dx.doi.org/10.1016/S0925-5273(97)00133-3

Bayrakdaroğlu, A., \& Ege, İ. (2008). Türkiye'deki Bankaların Performansının Analitik Hiyerarşi Süreci İle Değerlendirilmesi Üzerine Bir Model Önerisi. TÜİ İstatistik Araştırma Sempozyumu, Ankara.

Bodur, Ç., \& Suat T. (2005). Ticari Firmaların Kredi Derecelendirmesi: İMKB Firmalarına Uygulanması. İT̈̈ Dergisi/b, Sosyal Bilimler, 2(1), 25-36.

Chandran, B., Golden, B., \& Wasil E. (2005). Linear Programming Models For Estimating Weights in The Analytic Hierarchy Process. Computers And Operations Research, 32(9), 2235-2254. http://dx.doi.org/10.1016/j.cor.2004.02.010

Çelik, P., \& Topsakal, Y. (2015). Examining Hotel Selection Criterias of Golf Tourists By Analytic Hierarchy Process. The Macrotheme Review, 4(4), 65-76.

Hogan, K. M., Oolson, G., \& Rahmlow, H. (2000). A Model for the Prediction of Corporate Bankruptcy Using the Analytic Hierarchy Process. Multi-Criteria Applications, 10, 85-102.

İç, Y. T., \& Yurdakul, M. (2000). Analitik Hiyerarşi Süreci (AHS) Yöntemini Kullanan Bir Kredi Değerlendirme Sistemi. Gazi Üniversitesi Mühendislik Mimarllk Fakültesi Dergisi, 15(1), 1-14.

Koç, S. (2013). Bankaların Karşılaştıkları Riskleri Yönetmedeki Etkinliği: Türkiye Ölçeği. Maliye Dergisi, 165, 275-297.

Kuruüzüm, A., \& Atsan, N. (2001). Analitik Hiyerarşi Yöntemi ve İşletmecilik Alanındaki Uygulamaları. Akdeniz İ.̇.B.F. Dergisi, 1, 83-105.

Lin, Q., Li, D. D., \& Yang, Y. B. (2013). VIKOR Method with Enhanced Accuracy for Multiple Criteria Decision Making in Healthcare Management. Journal of Medical Systems, 37(1), 9908-9908.

Özyörük, B., \& Özcan, E. C. (2008). Analitik Hiyerarşi Sürecinin Tedarikçi Seçiminde Uygulanması: Otomotiv Sektöründen Bir Örnek. SDÜ İktisadi ve İdari Bilimler Fakültesi Dergisi, 13(1), 133-144.

Palaz, H., \& Kovancı, A. (2008). Türk Deniz Kuvvetleri Deniz Altılarının Seçiminin AHP ile Değerlendirilmesi. Havacıllk ve Uzay Teknolojileri Dergisi, 3(3), 53-60.

Palcic, I., \& Lalic, B. (2009). Analytical Hierarchy Process As a Tool For Selecting And Evaluating Projects. Int J Simul Model, 8(1), 16-26. http://dx.doi.org/10.2507/IJSIMM08(1)2.112

Peng, X., \& Dai, F. (2009). Information Systems Risk Evaluation Based on The AHP-fuzzy Algorithm. International Conference on Networking and Digital Society, 178-180. http://dx.doi.org/10.1109/icnds.2009.124

Saaty, T. L. (1990). An Exposition of The AHP in Reply To The Paper "Remarks On The Analytic Hierarchy Process. Management Science, 36(3), 259-268. http://dx.doi.org/10.1287/mnsc.36.3.259

Saaty, T. L. (2008). Relative Measurement and Its Generalization in Decision Making Why Pairwise Comparisons are Central in Mathematics for the Measurement of Intangible Factors The Analytic Hierarchy/Network Process. Review of the Royal Spanish Academy of Sciences Series a Mathematics (RACSAM), 102(2), 251-318. http://dx.doi.org/10.1007/BF03191825

Saaty, T. L., \& Özdemir, S. M. (2003). Why The Magic Number Seven Plus or Minus Two. Mathematical and Computer Modelling, 38(3-4), 233-244. http://dx.doi.org/10.1016/S0895-7177(03)90083-5

Sekreter, M. S., Akyüz, G., \& İpekçi Çetin, E. (2004). Şirketlerin Derecelendirilmesine İlişkin Bir Model Önerisi: Gıda Sektörüne Yönelik Bir Uygulama. Akdeniz I.I.I.B.F. Dergisi, 8, 139-155.

Tekindal, B., \& Erümit, A. K. (2007). Analitik Hiyerarşi Süreci (AHS) ve Bulanık AHS (AHS) Yöntemlerinin Yüksek Lisans Öğrencisi Seçimi Problemi Üzerinde Karşılaştırılması. Gazi Üniversitesi Endüstriyel Sanatlar Ĕ̈itim Fakültesi Dergisi, 21, 14-37.

Ülengin, F., \& Ülengin, B. (1994). Forecasting Foreign Exchange Rates: A Comparative Evaluation of AHP. $\begin{array}{llll}\text { International Journal of } & \text { Management }\end{array}$ http://dx.doi.org/10.1016/0305-0483(94)90031-0

Yang, J., \& Shia, P. (2002). Applying Analytic Hierarchy Process in Firm's Overall Performance Evaluation: A Case Study in China. International Journal of Business, 7(1), 31-46.

Yurdakul, M., \& İç, Y. T. (2004). AHS Approach in the Credit Evaluation of the Manufacturing Firms in Turkey. 
International Journal of Production $\quad$ Economics, $\quad 88, \quad 269-288$. http://dx.doi.org/10.1016/S0925-5273(03)00189-0

Yüksel, İ., \& Akın, A. (2006). Analitik Hiyerarşi Proses Yöntemiyle İşletmelerde Strateji Belirleme. Doğuş Üniversitesi Dergisi, 7(2), 254-268.

Zhou, Y. D., \& Shi, M. L. (2009). Rail Transit Project Risk Evaluation Based on AHP Model. Second International Conference on Information and Computing Science, 3, 236-238. http://dx.doi.org/10.1109/icic.2009.265

\section{Copyrights}

Copyright for this article is retained by the author(s), with first publication rights granted to the journal.

This is an open-access article distributed under the terms and conditions of the Creative Commons Attribution license (http://creativecommons.org/licenses/by/3.0/). 